Tropical Journal of Pharmaceutical Research February 2016; 15 (2): 259-266

ISSN: $1596-5996$ (print); 1596-9827 (electronic) (c) Pharmacotherapy Group, Faculty of Pharmacy, University of Benin, Benin City, 300001 Nigeria.

All rights reserved.

Available online at http://www.tjpr.org

Original Research Article

http://dx.doi.org/10.4314/tjpr.v15i2.6

\title{
Hepatoprotective Effect of Pandanus odoratissimus L Inflorescence Extracts in Acetaminophen-treated Guinea Pigs
}

\author{
Amina El-Shaibany ${ }^{1,2 \star}$, Molham AL-Habori ${ }^{3}$, Shaza Al-Massarani ${ }^{1}$, Ali El- \\ Gamal $^{1,4}$, Ali Al-Ajami ${ }^{5}$ and Adenan Al-Adhl ${ }^{6}$ \\ ${ }^{1}$ Department of Pharmacognosy, Pharmacy College, King Saud University, Riyadh, Saudi Arabia, ${ }^{2}$ Department of \\ Pharmacognosy, Faculty of Pharmacy, ${ }^{3}$ Department of Biochemistry \& Molecular Biology, Faculty of Medicine and Health \\ Sciences, University of Sana'a, Sana'a, Yemen, ${ }^{4}$ Faculty of Pharmacy, Mansoura University, El-Mansoura, Egypt, ${ }^{5}$ Department \\ of Botany, Faculty of Science, Dhamar University, Yemen, ${ }^{6}$ Department of Pharmacology, Faculty of Medicine and Health \\ Sciences, University of Sana'a, Sana'a, Yemen
}

*For correspondence: Email: aminashaibani@yahoo.com

Received: 18 September 2015

Revised accepted: 2 January 2016

\begin{abstract}
Purpose: To investigate the hepatoprotective activity of methanol extracts of peduncles, flowers and spathes of Pandanus odoratissimus L. inflorescence in acetaminophen-induced hepatotoxicity in guinea pigs.

Methods: The animals were randomly assigned to 9 groups ( 3 animals per group) and treated orally for 10 consecutive days. Group 1 served as normal control and received distilled water (1 $\mathrm{ml} / \mathrm{kg})$; groups 2 4 received methanol extracts of peduncle, flower, and spathes of $P$. odoratissimus $L$. (500 $\mathrm{mg} / \mathrm{kg}$ ), respectively, in the absence of acetaminophen (APAP); group 5 served as hepatotoxic control and received APAP (3 g/kg) on days 1 and 2; group 6 served as standard treatment group and received silymarin (100 $\mathrm{mg} / \mathrm{kg})+3 \mathrm{~g} / \mathrm{kg}$ APAP on days 1 and 2; groups 7 - 9 received methanol extracts of peduncle, flower, and spathes of $P$. odoratissimus $L$. (500 $\mathrm{mg} / \mathrm{kg}$ ) respectively $+3 \mathrm{~g} / \mathrm{kg} A P A P$ on days 1 and 2. Serum enzyme activities (AST, ALT, ALP) and total bilirubin were determined. Histopathological examinations of the liver were also carried out.

Results: The methanol extract of the peduncle alleviated the liver damage induced by APAP as evident by the improved histopathology picture similar to that of silymarin which presented with only mild hydropic and fatty changes. The extract also reduced the liver enzymes - AST, ALT and ALP - by 42, 50 and $59 \%$, respectively $(p<0.05)$, but the reduction (32\%) in total bilirubin was not significant $32 \%$. On the other hand, the flower extract only lowered AST and ALP by 31 and $48 \%(p<0.05)$, respectively, while the reduction in ALT and total bilirubin by 33 and $18 \%$ respectively, was not significant.

Conclusion: P. odoratissimus L. peduncle has potential hepatoprotective activity against APAPinduced hepatotoxicity in guinea pigs.
\end{abstract}

Keywords: Pandanus odoratissimus L., Peduncle, Flowers, Hepatoprotection, Acetaminophen, Guinea pigs

Tropical Journal of Pharmaceutical Research is indexed by Science Citation Index (SciSearch), Scopus, International Pharmaceutical Abstract, Chemical Abstracts, Embase, Index Copernicus, EBSCO, African Index Medicus, JournalSeek, Journal Citation Reports/Science Edition, Directory of Open Access Journals (DOAJ), African Journal Online, Bioline International, Open-J-Gate and Pharmacy Abstracts

\section{INTRODUCTION}

Drug-induced liver injury is a potential complication of virtually every prescribed medication because the liver has a central role in the metabolism of all drugs and toxic substances [1]. Acetaminophen ( $\mathrm{N}$-acetyl-p-aminophenol, Paracetamol; APAP) is a widely used analgesic 
and antipyretic drug that is safe and effective when taken at therapeutic doses [2]. However, when administered in an acute or cumulative overdose it can cause severe liver damage or even acute liver failure that can be fatal in experimental animals and humans [3,4]. Acetaminophen is metabolized by cytochrome P450 to N-acetyl-p-benzoquinone-imine (NAPQI), which can react rapidly with glutathione (GSH) [5], so that large doses of APAP may result in a profound depletion of hepatocellular GSH [2,5]. Once GSH is exhausted; any remaining NAPQI will covalently bind to cellular proteins and induce mitochondrial dysfunction, lipid peroxidation, oxidative stress, and DNA fragmentation, eventually leading to massive hepatocyte necrosis, liver damage or death $[5,6]$.

Pandanus odoratissimus L., a shrub, belongs to the family Pandanaceae found along the coast of India and in Andaman Islands, Western Malaysia; known by locals in India as Ketaki, is used in Ayurvedic medicine to treat backache, headache, rheumatic diseases, while the flowers and roots of Ketaki are described to treat leprosy, constipation and urinary complains [7,8]. Traditional healers of Villupuram (Tamil Nadu, India) uses the young tender shoots of Pandanus spp. along with overnight soaked boiled rice water as a treatment to cure patients suffering from severe jaundice [9].

Preliminary phytochemical screening of crude leaf extracts of $P$. odoratissimus $L$. showed the presence of alkaloids, saponins, flavonoids, and steroids [10,11]. Chemical component analysis of the root parts led to the isolation of two phenolic compounds, four lignan type compounds plus a new benzofuran derivative which showed strong antioxidative activities [12]. P. odoratissimus $L$. (whole plant) exhibit significant antitumor and antioxidant activities [13]; and its leaves possess potential CNS-depressant action [14] as well as anti-inflammatory activity [15]. Moreover, the leaves are reported to have natural antioxidant properties [16,17] and moderate activity against gram-positive bacteria [15].

Recently, the methanolic peduncle extract was shown to have a potential antioxidant activity [18]. The wide range of traditional and pharmacological activities observed for $P$. odoratissimus L. encouraged us to explore the potential hepatoprotective activity of $P$. odoratissimus L. inflorescence (peduncle, flower, spathes) extracts on the APAP-induced hepatotoxicity in guinea pigs.

\section{EXPERIMENTAL}

\section{Plant material}

The inflorescence of Pandanus odoratissimus L. was collected from Surdud Valley in Hodaidah, Yemen (December 2012 - January 2013) and identified by a taxonomist (Dr A Al-Ajami). A voucher specimen (no. 112) was deposited at the herbarium of Department of Pharmacognosy, Faculty of Pharmacy, Sana'a University. The different parts of the inflorescence (peduncle, flowers, and spathes) were separated and left to dry in a shade away from sunlight and moisture.

\section{Extraction and fractionation}

The air dried powdered peduncle, flowers and spathes of $P$. odoratissimus $L$. was separately extracted by maceration with $85 \%$ methanol $(5 \mathrm{x}$ $2 \mathrm{~L})$ at room temperature. The combined obtained methanol extracts of each part were dried and concentrated, using rotary evaporator, to give a dark crude residue (MET). The semi-solid residue of the total extracts of peduncle, flowers and spathes were suspended in water and partitioned successively for several times with petroleum ether, chloroform, ethyl acetate and nbutanol to provide the corresponding extracts. Each fraction was dried over anhydrous sodium sulphate and evaporated to dryness to yield fractions PET (petroleum ether), CET (chloroform), EET (ethyl acetate), BET (nbutanol) and AEA (remaining aqueous mother liquor) fractions.

\section{Preliminary phytochemical screening}

A preliminary phytochemical analysis of the different inflorescence (peduncle, flowers and spathes) obtained extracts was carried out using thin layer chromatography (TLC) plates coated with silica gel 60 F254 for TLC. The mobile phase ethyl acetate: methanol: water (30:5:4) was used. Micro-drops of the concentrated solutions of the fractions obtained (methanol, petroleum ether, chloroform, ethyl acetate, nbutanol and aqueous extracts) were spotted on pre-coated Silica gel plates. The chromatogram after complete development was air dried and visualized with different chemical reagents (see Table 1) to detect the presence of flavonoids, phenols, tannins, alkaloids, steroids, amino acids, saponins, and triterpenes glycosides.

\section{Experimental animals}

Guinea pigs (500 - $600 \mathrm{~g}$ ) were used and the animals were fed with standard animal feed and water and acclimatized to laboratory conditions 
for 3 weeks prior to experimentation. All experiments carried out were approved by the Institutional Ethical Committee, Faculty of Medicine and Health Sciences, Sana'a University (approval no. 762-15/01/2013) and were conducted according to standard guidelines for the use of laboratory animals [19].

\section{Determination of hepatoprotective activity}

For the determination of the hepatoprotective activity of the inflorescence (peduncle, flower and spathe) of $P$. odoratissimus L., 27 guinea pigs (500 - $600 \mathrm{~g}$ ) were used and randomly assigned to 9 groups ( 3 animals per group). All guinea pigs were treated orally for 10 consecutive days. Group 1 served as normal control group and received distilled water (1 $\mathrm{ml} / \mathrm{kg}$ body weight); groups 2 - 4 received only methanol extracts of peduncle, flower, and spathes of $P$. odoratissimus L. $(500 \mathrm{mg} / \mathrm{kg})$ respectively in the absence of APAP; group 5 served as hepatotoxic control received APAP (3 g/ $/ \mathrm{kg}$ ) on days 1 and 2; group 6 served as standard treated with silymarin $(100 \mathrm{mg} / \mathrm{kg})$ for 10 days $+3 \mathrm{~g} / \mathrm{kg}$ APAP on days 1 and 2; groups 7 - 9 received methanol extracts of peduncle, flower, and spathes of $P$. odoratissimus L. $(500 \mathrm{mg} / \mathrm{kg})$ respectively +3 $\mathrm{g} / \mathrm{kg}$ APAP on days 1 and 2 . Acetaminophen was administered one hour before the administration of either silymarin or the inflorescence extracts. At the end of the treatment period all animals were anaesthetized with ether and blood was collected by cardiac puncture into plain dry tubes and centrifuged at 3,000 rpm for $10 \mathrm{~min}$.

\section{Biochemical analysis}

The serum samples obtained were transferred into Eppendorf tubes and were analyzed by Cobas C 311 analyzer (Roche Diagnostics GmbH, D-68298 Mannheim, Germany) for estimation of liver enzymes: aspartate aminotransferase (AST), alanine aminotransferase (ALT) and alkaline Phosphatase (ALP), as well as total bilirubin using commercially available kits (Roche Diagnostics $\mathrm{GmbH}$, Mannheim, Germany).

\section{Histological examinations}

The excised liver of the sacrificed guinea pigs was rinsed in ice cold normal saline and tissue samples of control and treated guinea pigs were taken and fixed in $10 \%$ formalin neutral buffer solution. The trimmed tissues were first washed with tap water followed by dehydration through a graded series of alcohol, cleared in xylene and embedded in paraffin wax. The paraffin blocks were cut into $5-6 \mathrm{~mm}$ sections using a microtome and were mounted on slides and stained using hematoxylin and eosin. The slides were then examined under a light microscope.

\section{Statistical analysis}

The results are presented as mean \pm standard deviation (SD). The statistical analyses were performed on Statistical Package of Social Sciences (SPSS) version 11.5 (SPSS Inc, Chicago, IL, USA) using one way analysis of variance (ANOVA) followed by Dunnett's method to compare the groups. $P<0.05$ was considered statistically significant.

\section{RESULTS}

Preliminary phytochemical examination of the different fractions (Table 1) revealed the presence of flavonoids, phenolic compounds, steroids/ amino acids, and triterpenes glycosides in methanol, ethyl acetate, n-butanol and aqueous extracts of $P$. odoratissimus $\mathrm{L}$. inflorescence parts (peduncle, flowers and spathes). No alkaloids were detected in any of the extracts. Persisting foam was formed in all of the extracts suggesting the presence of saponins.

Table 2 shows the effect of methanol extracts of $P$. odoratissimus $\mathrm{L}$. inflorescence and silymarin on liver function tests in both normal and APAPtreated guinea pigs. In the untreated animals with APAP, both peduncle and flower methanol extracts showed no significant effect on the liver enzymes tested as well as total bilirubin. In contrast, AST, ALT, ALP and total bilirubin levels were significantly higher $(p<0.05)$ in animals exposed to spathes methanol extract (by 2.3, 2.3, 2.1, and 6.3-fold, respectively) when compared with the normal control group animals. Animals treated with APAP showed significantly raised $(p<0.05)$ levels of AST (2.2-fold), ALT (2.1-fold), ALP (84.8\%) and total bilirubin (6.3fold) with respect to the normal control group. However, silymarin $(100 \mathrm{mg} / \mathrm{kg})$ treatment lowered the increased levels of these enzymes by 47,53 , and $64 \%$, respectively, with a nonsignificant reduction in total bilirubin by $34 \%$. Similarly, peduncle $(500 \mathrm{mg} / \mathrm{kg})$ extract lowered the levels of AST, ALT and ALP by 42,50 and 59 $\%$ respectively, with a non-significant reduction in total bilirubin by $32 \%$. On the other hand, flower extracts only lowered the levels of AST and ALP by 31 and $48 \%$, with a non-significant reduction in ALT and total bilirubin by 33 and $18 \%$ respectively. Animals exposed to APAP and spathes were in general compromised health 
state and were sacrificed on the third day and their excised liver underwent histopathological examination.

Microscopic examination of liver sections from the control group and those exposed to the methanol extracts of the peduncles and flowers without the APAP showed a normal hepatic architecture with distinct hepatic cells, sinusoidal spaces and a central vein (Figures 1A, 1B and $1 \mathrm{C}$, respectively), whereas those exposed to spathes methanol extract showed inflammation, congestion and area of necrosis (Figure 1D). Acetaminophen-intoxicated group exhibited moderate hydropic change, fatty change inflammation and congestion (Figure 2E1+2). However, APAP with silymarin (100 mg/kg) showed only mild hydropic and fatty changes (Figure $2 \mathrm{~F} 1+2$ ). The group that was treated with $500 \mathrm{mg} / \mathrm{kg}$ of $P$. odoratissimus $\mathrm{L}$. peduncle showed similar histopathological changes to that of silymarin presented as mild hydropic and fatty changes (Figure 2G), while those treated with the flower extracts showed moderate hydropic and fatty changes (Figure $2 \mathrm{H} 1+2$ ). In contrast, the group treated with spathes extracts demonstrated inflammation, congestion and large area necrosis by the third day of treatment (Figure 1J1+2).

Table 1: Phytochemical profile of the peduncle, flowers and spathes of Pandanus odoratissimus $\mathrm{L}$

\begin{tabular}{|c|c|c|c|c|c|c|c|c|c|c|c|c|c|c|c|c|c|c|c|}
\hline \multirow{3}{*}{$\begin{array}{l}\text { Chemical } \\
\text { constituent }\end{array}$} & \multirow{3}{*}{$\begin{array}{c}\text { Chemical } \\
\text { test }\end{array}$} & \multicolumn{18}{|c|}{ Extract } \\
\hline & & \multicolumn{3}{|c|}{ MET } & \multicolumn{3}{|c|}{ PET } & \multicolumn{3}{|c|}{ CET } & \multicolumn{3}{|c|}{$E E T$} & \multicolumn{3}{|c|}{$B E T$} & \multicolumn{3}{|c|}{ AEA } \\
\hline & & $P$ & $F$ & $S$ & $P$ & $F$ & $S$ & $P$ & $F$ & $S$ & $P$ & $F$ & $S$ & $P$ & $F$ & $S$ & $P$ & $F$ & $S$ \\
\hline \multirow[t]{2}{*}{ Flavonoids } & $\mathrm{KOH}$ & + & + & + & + & - & - & + & + & + & + & + & + & + & + & + & + & + & + \\
\hline & $\mathrm{AlCl}_{3}$ & + & + & + & + & - & - & + & + & + & + & + & + & + & + & + & + & + & + \\
\hline $\begin{array}{l}\text { Phenols } \\
+ \text { tannins }\end{array}$ & $\mathrm{FeCl}_{3}$ & + & + & + & - & - & - & - & - & - & + & + & + & + & + & + & + & + & + \\
\hline Alkaloids & $\begin{array}{c}\text { Dragendorff's } \\
\text { Reagent }\end{array}$ & - & - & - & - & - & - & - & - & - & - & - & - & - & - & - & - & - & - \\
\hline $\begin{array}{l}\text { Steroids } \\
+ \text { amino acids }\end{array}$ & $\begin{array}{c}\text { Vanillin } \\
\text { Reagent }\end{array}$ & + & + & + & + & - & + & + & + & - & + & + & + & + & + & + & + & + & + \\
\hline $\begin{array}{l}\text { Steroids and } \\
\text { triterpene } \\
\text { glycosides }\end{array}$ & $\begin{array}{c}\text { Acetic } \\
\text { anhydride } \\
\mathrm{H}_{2} \mathrm{SO}_{4}\end{array}$ & + & + & + & - & - & - & - & + & - & + & + & + & + & + & + & + & + & + \\
\hline
\end{tabular}

Table 2: Effect of $P$. odoratissimus L. Inflorescence methanol extracts and silymarin on liver function test in both normal and APAP-treated guinea pigs

\begin{tabular}{|c|c|c|c|c|}
\hline \multirow[b]{2}{*}{ Group } & \multicolumn{4}{|c|}{ Liver function test } \\
\hline & $A S T(U / L)$ & $A L T(U / L)$ & $A L P(U / L)$ & T. Bilirubin (mg/dl) \\
\hline Control & $57.6 \pm 3.75$ & $68.17 \pm 5.60$ & $93.88 \pm 5.59$ & $0.26 \pm 0.06$ \\
\hline Peduncle $(500 \mathrm{mg} / \mathrm{kg})$ & $66.24 \pm 7.70$ & $79.00 \pm 5.49$ & $94.90 \pm 2.54$ & $0.29 \pm 0.026$ \\
\hline Flower $(500 \mathrm{mg} / \mathrm{kg})$ & $70.62 \pm 3.75$ & $75.85 \pm 5.40$ & $97.52 \pm 4.43$ & $0.40 \pm 0.14$ \\
\hline Spathes $(500 \mathrm{mg} / \mathrm{kg})$ & $133.3 \pm 9.87^{a}$ & $159.8 \pm 16.12^{a}$ & $195.2 \pm 6.32^{a}$ & $1.90 \pm 0.36^{\mathrm{a}}$ \\
\hline$+\operatorname{APAP}(3 \mathrm{~g} / \mathrm{kg})$ & $125.7 \pm 5.94^{a}$ & $142.3 \pm 17.66^{a}$ & $173.5 \pm 9.84^{a}$ & $1.64 \pm 0.26^{a}$ \\
\hline $\begin{array}{l}\text { APAP + Siylmarin } \\
(100 \mathrm{mg} / \mathrm{kg}) \\
\text { APAP + Peduncle } \\
(500 \mathrm{mg} / \mathrm{kg}) \\
\text { APAP + Flower } \\
(500 \mathrm{mg} / \mathrm{kg})\end{array}$ & $\begin{array}{c}93.7 \pm 5.19^{\mathrm{D}} \\
(47 \%) \\
96.5 \pm 4.89^{\mathrm{D}} \\
(42 \%) \\
104.3 \pm 3.10^{\mathrm{b}} \\
(31 \%)\end{array}$ & $\begin{array}{c}103.23 \pm 3.87^{\mathrm{D}} \\
(53 \%) \\
105.12 \pm 4.33^{\mathrm{D}} \\
(50 \%) \\
117.7 \pm 4.55 \\
(33 \%)\end{array}$ & $\begin{array}{c}122.4 \pm 3.8^{\mathrm{D}} \\
(64 \%) \\
126.4 \pm 3.76^{\mathrm{b}} \\
(59 \%) \\
135.3 \pm 4.47^{\mathrm{b}} \\
(48 \%)\end{array}$ & $\begin{array}{c}1.17 \pm 0.03 \\
(34 \%) \\
1.20 \pm 0.026 \\
(32 \%) \\
1.39 \pm 0.036 \\
(18 \%) \\
\end{array}$ \\
\hline
\end{tabular}

Values are expressed as mean $\pm S D,{ }^{a} p<0.05$ compared with control group; ${ }^{b} p<0.05$ compared with APAP group 


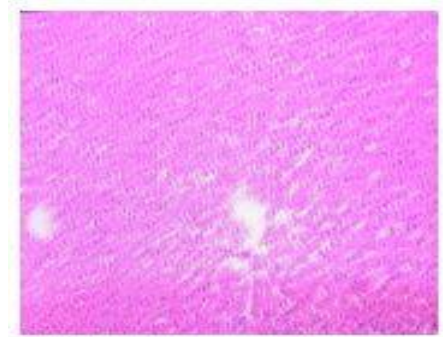

(A)

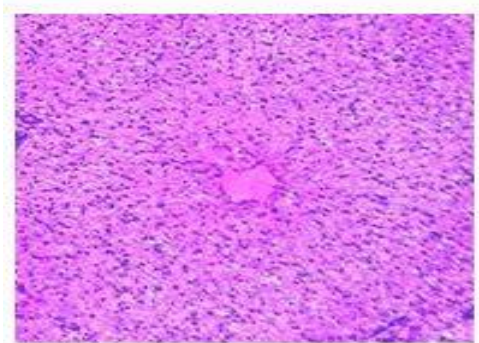

(C)

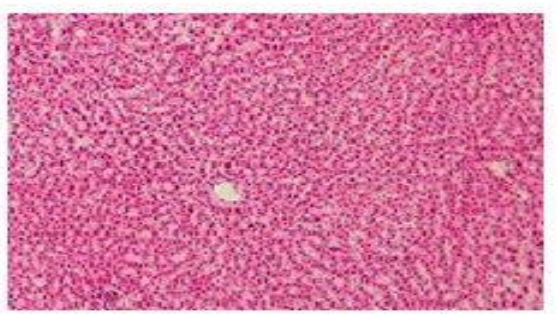

(B)

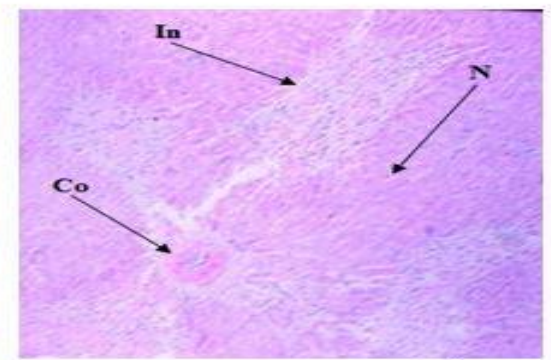

(D)

Figure 1: Histopathological observations (liver sections stained with Hematoxylin and Eosin, magnification $x 100$ ) showing the effects of different parts of $P$. odoratissimus $\mathrm{L}$. inflorescence extracts on normal guinea pigs liver. (A) Control, (B) Peduncle extract (500 mg/kg), (C) Flower extract (500 mg/kg), and (D) Spathes extract (500 mg/kg). (Co = Congestion, In = Inflammation, $\mathrm{N}=$ Necrosis)

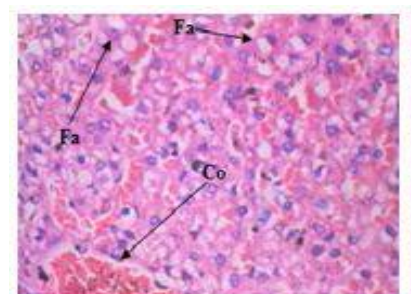

(E1)

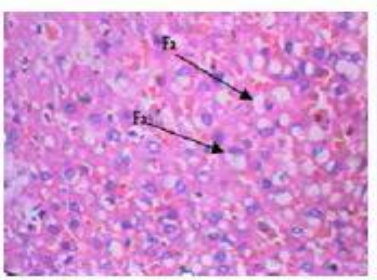

(F2)

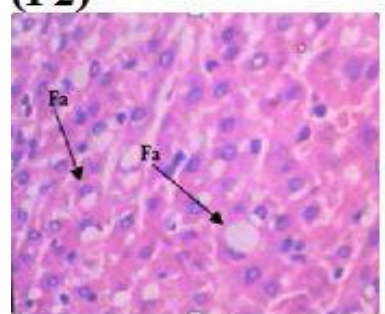

(H2)

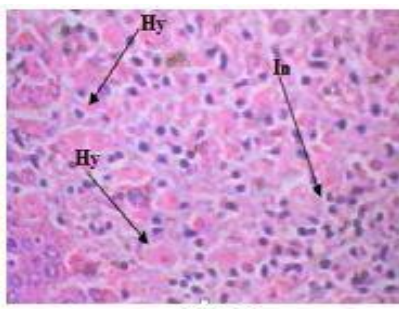

(E2)

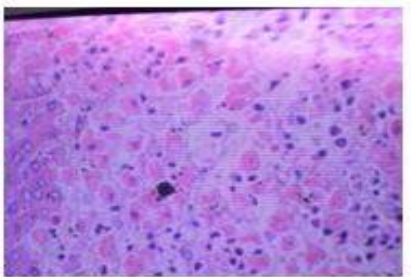

(G)

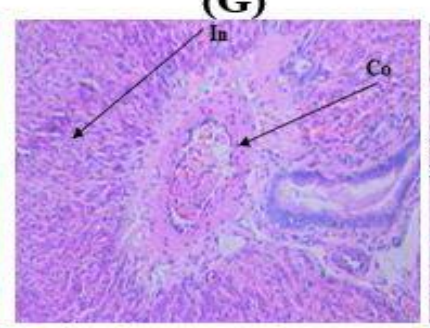

(J1)

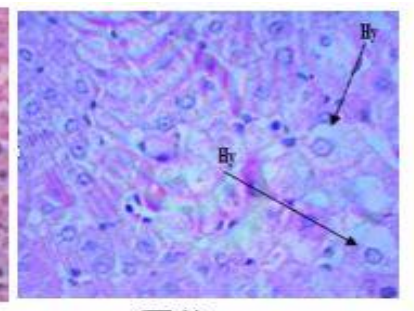

(F1)

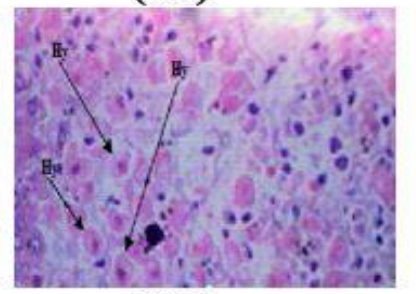

(H1)

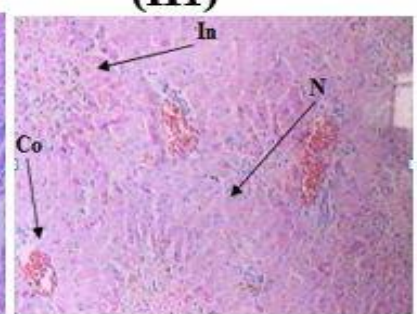

(J2)

Figure 2: Histopathological observations (liver sections stained with Hematoxylin and Eosin, magnification x 100) showing the effects of $P$. odoratissimus $\mathrm{L}$. inflorescence extracts on acetaminophen-induced histopathological changes in guinea pigs liver. $(E)$ acetaminophen-treated group, $(F 1+2)$ acetaminophen group treated with silymarin $(100 \mathrm{mg} / \mathrm{kg})$, (G) acetaminophen group treated with peduncle extract $(500 \mathrm{mg} / \mathrm{kg})$, $(\mathrm{H} 1+2)$ acetaminophen group treated with flower extract $(500 \mathrm{mg} / \mathrm{kg})$, and $(\mathrm{J})$ acetaminophen group treated with spathe extract $(500 \mathrm{mg} / \mathrm{kg})$. (Co = Congestion, In = Inflammation, $\mathrm{N}=$ Necrosis; Fa = Fatty change inflammation, Hy = Hydropic change) 


\section{DISCUSSION}

Several studies have demonstrated the induction of hepatocellular damage or necrosis by APAP overdose in experimental animals and in humans [20]. For screening of hepatoprotective agents, APAP-induced hepatotoxicity has been used as a reliable method. It is generally acknowledged that liver injury caused by APAP is associated with oxidative stress and free radicals. The overproduction of free radicals could directly injure hepatocellular membrane by lipid peroxidation or other means, followed by a series of cascades of cellular events such as the massive release of inflammatory mediators or cytokines, which eventually leads to liver damages [21]. Moreover, APAP overdose has been reported to cause acute centrilobular hepatic necrosis in humans and experimental animals [22].

In this study, it was found that APAP (3 g/ $/ \mathrm{kg})$ induced marked acute hepatotoxicity that was manifested by increases in serum AST, ALT, ALP and total bilirubin; and confirmed by severe histological changes in liver including moderate hydropic change, fatty change inflammation and congestion. The observed rise in serum levels of transaminases (AST and ALT) and ALP have been attributed to the damaged structural integrity of the liver, because these are normally located in the cytoplasm and are released into the circulation after cellular damage [23]. Elevation in the levels of bilirubin has been reported in APAP-induced hepatotoxicity [24]. Bilirubin level is also considered as one of the liver function tests as it reflects the functional integrity of the liver.

Our data indicate that silymarin administration significantly alleviate these enzyme levels and injury in liver. Silymarin has been reported to possess a powerful free radical scavenging properties [25], as well as stabilizing cell membrane and regulates the intracellular contents of the reduced GSH. In addition, silymarin stimulates RNA and protein synthesis leading to faster regeneration, repair, and renovation after liver injury [26]. Therefore, the observed reversal of increased serum enzymes in APAP-induced liver damage reflects the mentioned properties of silymarin. This is also in agreement with the commonly accepted view that serum levels of transaminases return to normal with the healing of hepatic parenchyma and the regeneration of hepatocytes [27].

Since hepatic damage induced by APAP is mediated by its free radical metabolites [28], antioxidant activity or inhibition of the generation of free radicals is important in the protection against APAP-induced liver injury [29]. It has been reported that $P$. odoratissimus $L$. (whole plant) exhibits significant antitumor and antioxidant activities in Ehrlic ascites carcinoma bearing mice [13]; and its leaves possess moderate activity on antioxidant enzymes such as lipid peroxidase, catalase, superoxide dismutase and glutathione [16,17]. A recent study has also suggested that the methanolic peduncle extract of $P$. odoratissimus $L$. has a potential antioxidant activity [18]. Previous investigation into the hepatoprotective activity of the methanolic extract of $P$. odoratissimus $L$. leaf against $\mathrm{CCl}_{4}$-induced liver damage reported signs of restoration of liver damage to the normal state [17].

Our results provide first experimental evidence that $P$. odoratissimus $L$. peduncle extract improves APAP-induced acute liver damage and toxicity in guinea pigs, as shown by the decrease in serum liver enzyme activities (AST, ALT and ALP) and total bilirubin concentrations. This observed decrease was comparable to that of silymarin which is an established treatment for toxic liver damage, and moreover is worldwide used in traditional medicine for the treatment of hepatic diseases. Moreover, the liver morphology and histopathology findings confirmed the protective activity of the peduncle extract against the APAP-induced liver damage as it is evident by the moderate reversal of the hydropic change, fatty change inflammation and congestion induced by APAP. This improvement was also observed to a lesser extent in the flower extract (group 7).

Despite the fact that $P$. odoratissimus $\mathrm{L}$. peduncle extracts significantly reduced ALT, AST and ALP levels, it did not completely restore these biochemical parameters to the normal values. However, the decrease in the serum levels of these enzymes may possibly be due to the presence of various antioxidant phytochemicals in the $P$. odoratissimus $\mathrm{L}$. peduncle and to some extent flower extracts that enhanced the regeneration ability of liver.

Moreover, the groups that received only methanol extract of the peduncle and flowers of $P$. odoratissimus $\mathrm{L}$. without the administration of APAP (groups 2 and 3) did not show any significant differences to the control group based on biochemical parameters (AST, ALT, ALP and total bilirubin) and the histopathological findings confirmed normal hepatic architecture and no signs of liver damage. Despite the similarity in the preliminary phytochemical screening, the spathes (the third part of the inflorescence) was 
unexpectedly highly hepatotoxic (group 4) even when administered to animals without APAP, as evident by the raised liver enzymes and total bilirubin to levels comparable to that of APAP (3 $\mathrm{g} / \mathrm{kg}$ ) as well as the severe histological liver changes as shown by inflammation, congestion and necrosis. This raises the question as to the toxicity of one part of the inflorescence which is in close proximity to the other parts and merits further phytochemical studies.

\section{CONCLUSION}

The results presented in this study show that the various parts of Pandanus odoratissimus $\mathrm{L}$. Inflorescence (mainly peduncle and to a lesser extent flowers) possess potential hepatoprotective activity against APAP-induced hepatotoxicity as evident by the improved histopathology damage induced by APAP as well as decreased serum liver enzyme activities and total bilirubin concentrations. This may have relevant clinical therapeutic significance in the repair of damaged hepatocytes and restoration of normal liver functions in humans. Further studies are, however, required for structural elucidation of the active component(s) involved in the hepatoprotection and for clinical trials.

\section{ACKNOWLEDGEMENT}

This research was supported by a grant (RGPVPP-326) from Deanship of Scientific Research, King Saud University. The authors arethankful to Maki Ghaleb (University of Sana'a) for collecting the plant material and to Ibrahim Al-Hurybi and Afnan Al-Sunaidar (University of Sana'a) for their assistance in the statistical analysis.

\section{REFERENCES}

1. Marotta F, Yadav H, Gumaste U, Helmy A, Jain S, Minelli E. Protective effect of a phytocompound on oxidative stress and DNA fragmentation against paracetamol induced liver damage. Ann Hepatol 2009; 8: 50-56.

2. Rumack BH. Acetaminophen misconceptions. Hepatology 2004; 40: 10-15.

3. Lee WM. Acetaminophen and the U.S. Acute Liver Failure Study Group: Lowering the risks of hepatic failure. Hepatology 2004; 40: 6-9.

4. Larson AM. Acetaminophen hepatotoxicity. Clin Liver Disease 2007; 11: 525-548.

5. McGill MR, Sharpe MR, Williams CD, Taha M, Curry SC, Jaeschke $H$. The mechanism underlying acetaminophen-induced hepatotoxicity in humans and mice involves mitochondrial damage and nuclear DNA fragmentation. J Clin Invest 2012; 122: 1574-1583.
6. Hinson JA, Reid AB, McCullough SS, James $L P$. Acetaminophen-induced hepatotoxicity: Role of metabolic activation, reactive oxygen/ nitrogen species, and mitochondrial permeability transition. Drug Metab Rev 2004; 36: 805-822.

7. Khare CP. Indian Herbal Remedies: Rational Western therapy, Ayurvedic and other traditional usage, botany. Springer-Verlag 2004; $p 524$.

8. Ilanchezhian R, Roshy Joseph C. Hepatoprotective and hepatocurative activity of the traditional medicine ketaki (Pandanus odoratissimus Roxb.): An experimental evaluation. Asian J Tradit Med 2010; 5(6): 212-218.

9. Sankaranarayanan $S$, Bama $P$, Ramachandran J, Kalaichelvan PT, Deccaraman M, Vijayalakshimi $M$, et al. Ethnobotanical study of medicinal plants used by traditional users in Villupuram district of Tamil Nadu, India. J Med Plants Res 2010; 4: 1089-1101.

10. Sasikumar JM, Jinu U, Shamna R. Antioxidant activity and HPTLC analysis of Pandanus odoratissimus $L$. root. Eur J Biol Sci 2009; 2: 17-22.

11. Kumar D, Kumar $S$, Kumar $S$, Singh J, Sharma $C$, Aneja $K R$. The antimicrobial and preliminary phytochemical screening of crude leaf extract of Pandanus odoratissimus L. Pharmacol Online 2010; 2: 600-610.

12. Jong TT, Chau SW. Antioxidative activities of constituents isolated from Pandanus odoratissimus. Phytochemistry 1998; 49: 2145-2148.

13. Panigrahi BB, Panda PK, Patro VJ. Antitumor and in vivo antioxidant activities of Pandanus odoratissimus Linn. against Ehrlich ascites carcinoma in Swiss albino mice. Int J Pharmaceut Sci Rev Res 2011; 8(2): 202-208.

14. Raju S, Subbaiah NV, Reddy KS, Das A, Murugan KB. Potential of Pandanus odoratissimusas a CNS depressant in Swiss albino mice. Brazilian $J$ Pharmaceut Sci 2011; 47(3): 629-634.

15. Londonkar R, Kamble A, Chinnappa Reddy V. Antiinflammatory activity of Pandanus odoratissimus extract. Int J Pharmacol 2010; 6(3): 311-314.

16. Londonkar $R$, Kamble $A$. Evaluation of free radical scavenging activity of Pandanus odoratissimus. Int $J$ Pharmacol 2009; 5(6): 377-380.

17. Londonkar $R$, Kamble A. Hepatotoxic and in vivo antioxidant potential of Pandanus odoratissimus against carbon tetrachloride induced liver injury in rats. Oriental Pharmacy Experimental Med 2011; 11: 229-234.

18. El-Shaibany A. Nocturnal enuresis, antioxidant and antimicrobial activities of Pandanus odoratissimus $L$. peduncle. Int J Pharmaceut Sci Res 2014; 5(3): 811 818.

19. National Institute of Health, USA. Public health service policy on human care and use of laboratory animals; 2002.

20. Vermeulen NPE, Bessems JGM, Vande Streat $R$. Molecular aspects of paracetamol hepatotoxicity and it mechanism based prevention. Drug Metab Rev 1992; 24: 367-407. 
21. Jaeschke H. Reactive oxygen and mechanisms of inflammatory liver injury. J Gastroenterol Hepatol 2000; 15: 718-724.

22. Ita $S$, Akpanyung $E$, Umoh B, Ben E, Ukafia S. Acetaminophen induced hepatic toxicity: Protective role of Ageratum conyzoides. Pakistan J Nutr 2009; 8: 928932.

23. Ramaiah SK. A toxicologist guide to the diagnostic interpretation of hepatic biochemical parameters. Food Chem Toxicol 2007; 45: 1551-1557.

24. Aseervatham GS, Sivasudha T, Sasikumar JM, Christabel PH, Jeyadevi R, Ananth DA. Antioxidant and hepatoprotective potential of Pouteria campechiana on acetaminophen-induced hepatic toxicity in rats. $J$ Physiol Biochem 2014; 70: 1-14.

25. Kren V, Walterova $D$. Silybin and silymarin: New effects and applications. Biomed Papers 2005; 149: 29-41.
26. Patel N, Joseph C, Corcoran GB, Ray SD. Silymarin modulates doxorubicin-induced oxidative stress, $B c l-x L$ and p53 expression while preventing apoptotic and necrotic cell death in the liver. Toxicol Applied Pharmacol 2010; 245: 143-152.

27. Manna SK, Mukhopadhyay A, Van NT. Silymarin suppresses TNF-induced activation of NF-kB, c-Jun Nterminal kinase and apoptosis. J Immunol 1999; 163: 6800-6809.

28. Yoon MY, Kim SJ, Lee BH, Chung JH, Kim YC. Effects of dimethylsulfoxide on metabolism and toxicity of acetaminophen in mice. Biological and Pharmaceut Bulletin 2006; 29: 1618-1624.

29. Bhoopata L, Srichairatanakoob S, Kanjanapothic D. Hepatoprotective effects of lychee (Litchi chinensis Sonn.): A combination of antioxidant and anti-apoptotic activities. J Ethnopharmacol 2011; 136: 55-66. 